\title{
Living with a Pericardial Hydatid Cyst for 50 Years
}

\author{
Sinan Sahin, Ahmet Ozderya, Gulay Uzun, Muhammet Rasit Sayin \\ Department of Cardiology, Trabzon Ahi Evren Cardiovascular and Thoracic Surgery Research and Application Center, University of Health Sciences Turkey, Trabzon, \\ Turkey \\ ORCID: \\ Sinan Sahin: https://orcid.org/0000-0002-3687-0580 \\ Ahmet Ozderya: https://orcid.org/0000-0002-4369-6146 \\ Gulay Uzun: https://orcid.org/0000-0002-7848-5840 \\ Muhammet Rasit Sayin: https://orcid.org/0000-0002-2306-9954
}

\section{Abstract}

Isolated cardiac location is an uncommon presentation of echinococcosis and involvement of the pericardium is even rarer. It may lead to various complications or remain asymptomatic for a long time. We report a case of a 71-year-old woman with isolated pericardial hydatid cyst (without myocardial involvement) that observed with incidentally.

Keywords: Cyst, hydatid, pericardium

\section{INTRODUCTION}

Cardiac hydatid cysts are uncommon in cases of hydatid disease. Involvement of the heart accounts for $0.5 \%-2 \%$ of all hydatid cyst locations. ${ }^{[1]}$ It is extremely rare to come across pericardial involvement in cardiac hydatid cysts. ${ }^{[2]}$ We present a case of pericardial hydatid cyst who remain asymptomatic for roughly 50 years.

\section{Case Report}

A 71-year-old woman presented to our clinic after suspicious calcified cyst was seen on her chest X-ray [Figure 1a] prior to elective orthopedic surgery. The physical examination was unremarkable with the exception of a scar tissue on her chest which was due to a thoracotomy 50 years ago. There is no abnormal value in the patient's laboratory tests (white blood cell: $6.5310^{3} / \mu \mathrm{L}$, eosinophil: $0.0410^{3} / \mu \mathrm{L}$ ). Electrocardiography was in sinus rhythm. Transthoracic echocardiography identified acyst showing minimal compression to the left atrium with a size of $6 \mathrm{~cm} \times 3 \mathrm{~cm}$ [Figure 1b]. On the thoracic computed tomography scan, a heterogeneous, hypodense mass lesion with a heavily calcified

Received: 03-02-2021 Revised: 29-03-2021 Accepted: 13-04-2021

Published Online: 05-07-2021

\begin{tabular}{|l|l|}
\hline \multicolumn{3}{|c|}{ Access this article online } \\
\hline Quick Response Code: & Website: \\
& \\
http://www.ijcva.com
\end{tabular}

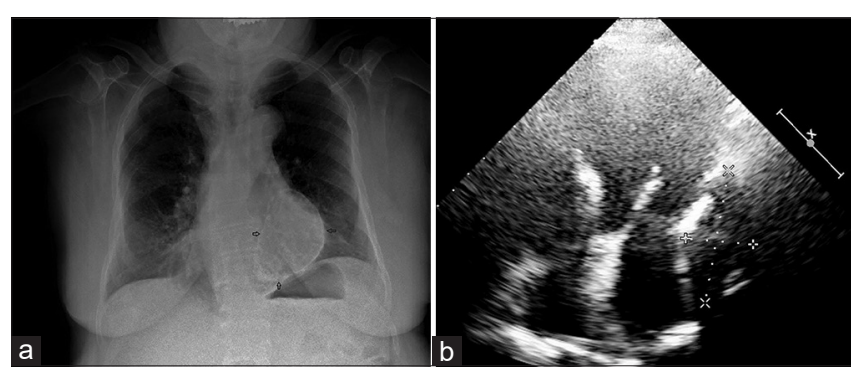

Figure 1: (a) Chest radiograph (b) Apical four chamber view of echocardiography

cyst of $6 \mathrm{~cm} \times 8 \mathrm{~cm}$ in size and radiolucent center was detected in the mediastinum medium in the left atrioventricular neighborhood [Figure 2a-d]. In patient's detailed medical history, there was a failed cyst operation from 50 years ago. The patient has had no complaints since then. There was no any medical document for that operation. The patient said

Address for correspondence: Dr. Ahmet Ozderya Trabzon Ahi Evren Cardiovascular and Thoracic Surgery Research and Application Center, University of Health Sciences, Turkey, Trabzon E-mail: ahmetozderya@gmail.com

This is an open access journal, and articles are distributed under the terms of the Creative Commons Attribution-NonCommercial-ShareAlike 4.0 License, which allows others to remix, tweak, and build upon the work non-commercially, as long as appropriate credit is given and the new creations are licensed under the identical terms.

For reprints contact: WKHLRPMedknow_reprints@wolterskluwer.com

How to cite this article: Sahin S, Ozderya A, Uzun G, Sayin MR. Living with a pericardial hydatid cyst for 50 years. Int J Cardiovasc Acad 2021;7:60-1. 


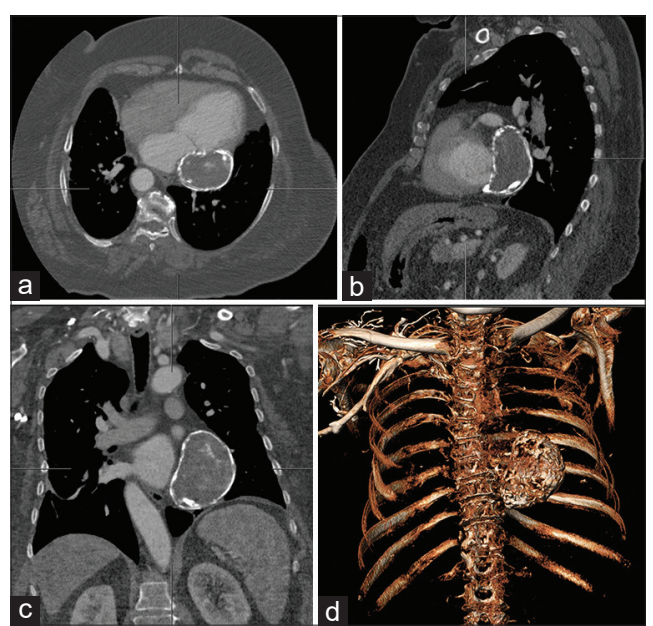

Figure 2: (a) Computed tomography, axial view of the cyst (b) Computed tomography, sagittal view of the cyst (c) Computed tomography, coronal view of the cyst (d) Computed tomography, volume rendering

that the surgery team at the time told her the cyst was caused by a disease transmitted from an animal. Since hydatid cysts caused by echinococcosis are usually calcified, we thought the underlying cause for the cyst would be echinococcosis. It is also important to note that during those years, hydatid disease was endemic in Turkey and neighboring countries. A second surgical operation was recommended to the patient. The patient did not accept the operation due to her age and no symptoms for 50 years. The patient has been followed up asymptomatically for 1 year.

\section{Discussion}

Cardiac hydatid cysts are uncommon in cases of hydatid disease. The cardiac location for these cysts are relatively rare compared to other organs in the area. For cardiac hydatid cysts, they are most frequently seen in the myocardial region especially in the left ventricular free wall and the interventricular septum. It is extremely rare to come across pericardial involvement in cardiac hydatid cysts. ${ }^{[2]}$ In our patient, the hydatid cyst was located inside the pericardial cavity without myocardial involvement. Clinical findings and complications vary according to the location of the cyst. ${ }^{[3]}$ It is common to see patients with cardiac hydatid cysts to remain asymptomatic for a long time with no or minimal complaints. Cardiac hydatid cysts may present with potentially life-threatening events such as cardiac tamponade, heart failure, syncope, arrhythmias, valvular stenosis or regurgitation, pulmonary hypertension, or peripheral embolism. ${ }^{[4]}$ However, there is a strong association between cardiac hydatid cysts and an increased risk of lethal complications. These complications involve ruptures causing cardiac tamponade, anaphylaxis as well as death if the underlying cause of hydatid disease is left untreated. In our case, we have not planned any surgical intervention for now, since the cyst has been calcified and asymptomatic for about 50 years and the patient did not accept a second operation.

\section{Declaration of patient consent}

The authors certify that they have obtained all appropriate patient consent forms. In the form, the patient has given her consent for her images and other clinical information to be reported in the journal. The patient understands that name and initials will not be published and due efforts will be made to conceal identity, but anonymity cannot be guaranteed.

\section{Financial support and sponsorship}

Nil.

\section{Conflicts of interest}

There are no conflicts of interest.

\section{REFERENCES}

1. Orhan G, Ozay B, Tartan Z, Kurc E, Ketenci B, Sargin M, et al. Surgery of cardiac hydatid cysts. Experience of 39 years. Ann Cardiol Angeiol (Paris) 2008;57:58-61.

2. Kosecik M, Karaoglanoglu M, Yamak B. Pericardial hydatid cyst presenting with cardiac tamponade. Can J Cardiol 2006;22:145-7.

3. Díaz-Menéndez M, Pérez-Molina JA, Norman FF, Pérez-Ayala A, Monge-Maillo B, Fuertes PZ, et al. Management and outcome of cardiac and endovascular cystic echinococcosis. PLoS Negl Trop Dis 2012;6:e1437.

4. Ambrosi P, Mesana T, Habib G, Boulain L, Lambert M, Simeoni JB, et al. Right intra-atrial extension of hydatid cyst mimicking cardiac thrombosis. Apropos of a case. Arch Mal Coeur Vaiss 1992;85:909-12. 